University of Nebraska - Lincoln

DigitalCommons@University of Nebraska - Lincoln

USDA National Wildlife Research Center - Staff Publications
U.S. Department of Agriculture: Animal and Plant Health Inspection Service

2017

\title{
Transmission of H6N2 wild bird-origin influenza A virus among multiple bird species in a stacked-cage setting
}

\author{
J. Jeffrey Root \\ USDA/APHIS/WS National Wildlife Research Center, jeff.root@aphis.usda.gov
}

Susan A. Shriner

USDA/APHIS/WS National Wildlife Research Center, susan.a.shriner@aphis.usda.gov

Jeremy W. Ellis

USDA National Wildlife Research Center

Kaci K. VanDalen

USDA/APHIS/WS National Wildlife Research Center, kaci.vandalen@aphis.usda.gov

Alan B. Franklin

USDA National Wildlife Research Center, alan.b.franklin@aphis.usda.gov

Follow this and additional works at: https://digitalcommons.unl.edu/icwdm_usdanwrc

Part of the Life Sciences Commons

Root, J. Jeffrey; Shriner, Susan A.; Ellis, Jeremy W.; VanDalen, Kaci K.; and Franklin, Alan B., "Transmission of H6N2 wild bird-origin influenza A virus among multiple bird species in a stacked-cage setting" (2017). USDA National Wildlife Research Center - Staff Publications. 1959.

https://digitalcommons.unl.edu/icwdm_usdanwrc/1959

This Article is brought to you for free and open access by the U.S. Department of Agriculture: Animal and Plant Health Inspection Service at DigitalCommons@University of Nebraska - Lincoln. It has been accepted for inclusion in USDA National Wildlife Research Center - Staff Publications by an authorized administrator of DigitalCommons@University of Nebraska - Lincoln. 


\title{
Transmission of H6N2 wild bird-origin influenza A virus among multiple bird species in a stacked-cage setting
}

\author{
J. Jeffrey $\operatorname{Root}^{1} \cdot$ Susan A. Shriner $^{1} \cdot$ Jeremy W. Ellis $^{1} \cdot$ Kaci K. VanDalen $^{1}$. \\ Alan B. Franklin ${ }^{1}$
}

Received: 7 December 2016/ Accepted: 8 March 2017/Published online: 16 May 2017

(C) Springer-Verlag Wien (Outside the USA) 2017

\begin{abstract}
Live bird markets are common in certain regions of the U.S. and in other regions of the world. We experimentally tested the ability of a wild bird influenza A virus to transmit from index animals to naïve animals at varying animal densities in stacked cages in a simulated live bird market. Two and six mallards, five and twelve quail, and six and nine pheasants were used in the low-density and high-density stacks of cages, respectively. Transmission did not occur in the high-density stack of cages likely due to the short duration and relatively low levels of shedding, a dominance of oral shedding, and the lack of transmission to other mallards in the index cage. In the low-density stack of cages, transmission occurred among all species tested, but not among all birds present. Oral and cloacal shedding was detected in waterfowl but only oral shedding was identified in the gallinaceous birds tested. Overall, transmission was patchy among the stacked cages, thereby suggesting that chance was involved in the deposition of shed virus in key locations (e.g., food or water bowls), which facilitated transmission to some birds.
\end{abstract}

\section{Introduction}

Live bird markets (LBM) are common in certain areas of the U.S. and abroad. For example, multiple LBMs are present in the northeastern U.S. [4], various locations in California, and other regions of the U.S. [24]; these

J. Jeffrey Root

Jeff.root@aphis.usda.gov

1 United States Department of Agriculture, National Wildlife Research Center, 4101 LaPorte Avenue, Fort Collins, CO 80521, USA markets persist in part due to people's preference for fresh animals $[5,19]$. These types of markets are also common in other regions of the world, such as Asia and Africa [1, 21], and often exist in these areas for the same reason listed above [1, 19], as well as due to limited capacities for refrigeration and frozen storage in some locations [6].

Avian influenza virus (AIV) can be a common problem in LBMs [5, 19]. For example, a low pathogenic (LP) AIV was detected in multiple LBMs in southern California during 2005 [5], and a highly pathogenic (HP) AIV has been detected in LBMs in Asia and Africa [1, 19]. In some instances, the conditions found in these types of markets are ideal for establishment and transmission of AIVs [19] and LBMs have been suggested as the viral source of previous outbreaks in commercial poultry in the northeastern U.S. [14]. Notably, LP H5 AIVs have been detected in LBMs in the northeastern U.S. as recently as the summer of 2016 [11].

A previous LBM study mimicking the southern California LBM system and using an H6N2 AIV (isolated from chickens) showed evidence of transmission among chickens by multiple routes [23]. A second study, which evaluated the potential of chickens to transmit a chickenadapted virus to other avian species, showed evidence of transmission to a high proportion of Japanese quail ( $\mathrm{Co}$ turnix coturnix japonica; $80 \%$ ), but only to a low proportion of Pekin ducks (Anas platyrhynchos var. domestica; $5 \%$ ) in an experimental LBM setting [22].

Introductions of AIVs continue to pose a threat to LBM systems, poultry production and public health. The plethora of market types found in LBMs globally suggests the need for evaluations of LBM arrangements to further assess the transmission of AIVs in these types of systems [22]. For these reasons, the objective of this study was to assess the transmission dynamics of AIV in a simulated multi-species 
LBM setting under two density treatments. To accomplish this, a LP AIV strain isolated from a wild bird was used to simulate the possibility of a wild bird introducing a virus into an open air market and/or to the flocks of Poultry production facilities for these markets.

\section{Materials and methods}

\section{Study animals}

A total of eight juvenile mallards (Anas platyrhynchos), 13 juvenile ring-necked pheasants (Phasianus colchicus), and 17 juvenile quail (Coturnix sp.) were utilized in this experiment. All bird handling and sampling followed a specific order from cage 1 to cage 9 (Figure 1). Daily sampling consisted of an oral swab, a cloacal swab, a fecal swab (from each cage, when present), and a water sample (from each cage, when present). All swab samples were stored in $1 \mathrm{~mL}$ of BA-1 viral transport media [15]. Animal procedures were approved by the Animal Care and Use Committee of the National Wildlife Research Center (NWRC).

Because transmission of AIV in LBMs is likely densitydependent, at least to some degree, stacks of bird cages were equipped with two different densities of birds. The low-density stack consisted of two juvenile mallards housed in one double-wide cage (first [top] level), two cages below the top level, one with two quail and one with three quail (second level), then two cages of one pheasant each (third level), and finally two cages of one pheasant each (fourth [bottom] level). In addition, two cages of one pheasant each were placed immediately adjacent to the first level of this stack (Figure 1). The high-density stack consisted of six juvenile mallards contained in one doublewide cage (first [top] level), two cages of six quail each (second level), two cages of two pheasants each (third level), and two cages containing two pheasants in one and one pheasant in the other (fourth [bottom] level). In addition, two cages of one pheasant each were placed immediately adjacent to the fourth level of this stack (Figure 1).

\section{Experimental infection}

On day 0 post infection (DPI), one of the two mallards in the low-density stack and two of the six mallards in the high-density stack were randomly selected and orally inoculated with approximately $10^{6} \mathrm{EID}_{50}$ of an avian-origin H6N2 AIV (A/wild bird/IL/183983-24/06[H6N2]) diluted to $1 \mathrm{~mL}$ in BA-1 diluent. These mallards were held separately for approximately 1.5 hours prior to being introduced into their respective stacks. These were the only animals that were intentionally infected during this study. An H6N2 AIV was chosen as inoculum because this subtype has been associated with LBM infections in the U.S. during previous years [5], H6 viruses are prevalent in LBMs in Asia [9], and H6 AIVs are commonly found in the wild bird fauna in the U.S. [10]. The experimental design allowed the assessment of virus transmission occurring downward among cage rows (i.e., top to bottom) and horizontally to adjacent cages. Cages remained stacked as described until the morning of 3 DPI, to represent a short duration (e.g., long weekend) LBM used in some live bird markets, at which time they were unstacked. Cages were then re-stacked in the same order during the afternoon of 4 DPI to assess transmission when infected birds are placed in LBMs at later time-points during the infection.

In the low-density stack, oral swabs and cloacal swabs were collected from each individual bird from 1-7 DPI and on $9,11,14$, and 16 DPI. In the high-density stack, oral and cloacal swabs were collected from 1-7 DPI and on 9 DPI. Water and fecal samples were opportunistically collected each day the birds in a given cage were sampled. All swab samples were stored in $1 \mathrm{~mL}$ of BA-1 viral transport media and stored on wet ice during animal processing and at $80^{\circ} \mathrm{C}$ prior to analyses.

Due to the nominal and short duration of shedding from the experimentally infected birds in the high-density stack, along with the lack of transmission to the uninfected birds observed via near real-time analyses, sampling was terminated for this stack and all birds were euthanized at 10 DPI. The remaining birds from the low-density stack were sampled for several more days and all birds were euthanized on 15 or 16 DPI, at which time a blood sample was taken.

\section{Laboratory testing}

Oral and cloacal swabs from birds and fecal swabs and water samples from cages were tested for viral RNA by RTPCR following published protocols [17] as described previously [13]. Positive samples were defined as those yielding two wells with positive amplifications (i.e., two plate wells of the same sample) with a $\mathrm{Cq}$ value of $\leq 38$. Serological assessments were conducted with FlockCheck ${ }^{\circledR}$ Avian Influenza MultiS-Screen Antibody Test Kit (IDEXX Laboratories, Inc., Westbrook, ME). This assay is intended to be species independent, but has not been validated for all of the species tested during the current study; therefore, in these instances, seroconversions were inferred from the differences in sample-to-negative ratios from pre- and postexperiment serum samples. 


\section{A}

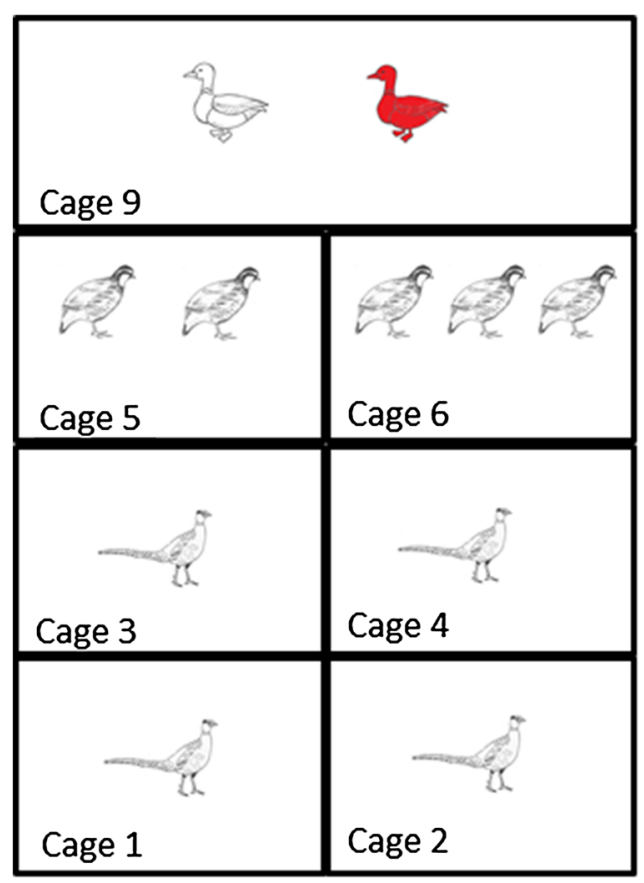

B


Fig. 1 Schematic of low-density (A) and high-density (B) stacks of cages. Each stack was always sampled in order from cage 1 to cage 9 , to avoid mechanical transmission by animal workers. Birds shown in

\section{Results}

\section{High-density stack}

Virus shedding was limited in the high-density stack. One of the experimentally inoculated mallards from this stack shed virus on a single day (1 DPI), while the second
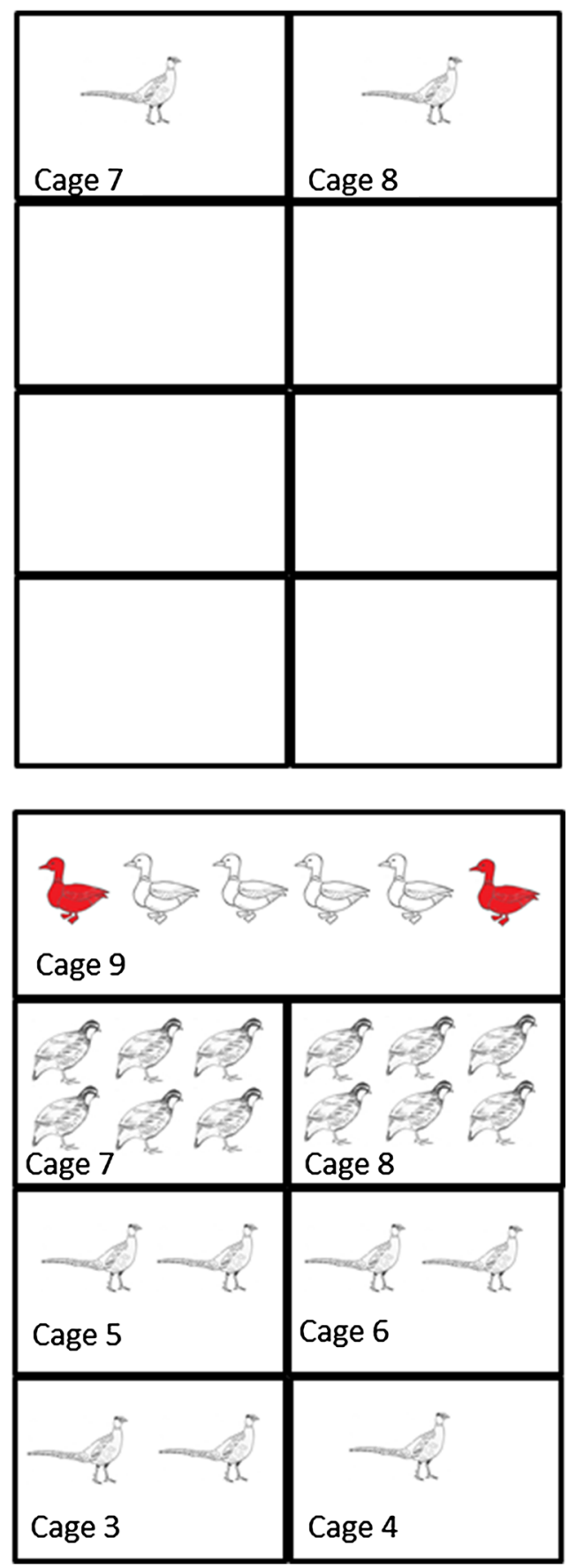

red are animals that were deliberately infected. Animal drawings were produced by Elizabeth Draves and Jeremy W. Ellis

experimentally inoculated mallard shed from 1-3 DPI (Table 1). Of interest, aside from a single DPI, only oral shedding was noted in both of these mallards. The paucity of cloacal shedding observed in this stack is indicative of minimal fecal shedding in these mallards. Not surprisingly, these mallards failed to transmit the virus to any of their cage mates or to other birds in the cages below them and 
Table 1 Influenza A viral RNA shedding and serology of experimentally infected birds and birds placed in direct or indirect contact with infected birds in a simulated live bird market. Only birds with evidence of infection (shedding or serology) are shown

\begin{tabular}{|c|c|c|c|c|c|c|c|c|c|c|c|c|c|c|c|}
\hline \multicolumn{4}{|c|}{ Experimental setup } & \multicolumn{11}{|c|}{ All birds (both stacks) positive for viral RNA or antibodies } & \multirow{3}{*}{$\begin{array}{l}\text { Serology } \\
\text { Multiple DPI }\end{array}$} \\
\hline & & & & \multicolumn{11}{|c|}{ Days post infection (mallards) } & \\
\hline $\mathrm{ID}^{\mathrm{a}}$ & Stack $^{\mathrm{b}}$ & Cage & Species & 1 & 2 & 3 & 4 & 5 & 6 & 7 & 9 & 11 & 14 & 16 & \\
\hline \multirow[t]{2}{*}{1568} & $\mathrm{LD}$ & 9 & Mallard & $\mathrm{O}^{\mathrm{d}}+++$ & ++ & + & - & - & + & + & - & - & - & - & $P(-0.60)$ \\
\hline & & & & $\mathrm{C}-$ & - & - & +++ & +++ & ++ & + & - & - & - & - & \\
\hline \multirow[t]{2}{*}{1575} & LD & 9 & Mallard & $\mathrm{O}-$ & + & + & - & ++ & + & + & + & + & - & - & $\mathrm{P}(-0.34)$ \\
\hline & & & & $\mathrm{C}-$ & - & - & - & - & +++ & + & ++ & - & + & - & \\
\hline \multirow[t]{2}{*}{756} & $\mathrm{LD}$ & 5 & Quail & $\mathrm{O}-$ & - & - & - & - & ++++ & ++ & +++ & - & - & - & $\mathrm{N}(+0.06)$ \\
\hline & & & & $\mathrm{C}-$ & - & - & - & - & - & - & - & - & - & - & \\
\hline \multirow[t]{2}{*}{770} & LD & 5 & Quail & $\mathrm{O}-$ & - & - & - & - & +++ & ++++ & ++++ & - & - & - & S (-0.14) \\
\hline & & & & $\mathrm{C}-$ & - & - & - & - & - & - & - & - & - & - & \\
\hline \multirow[t]{2}{*}{762} & LD & 6 & Quail & $\mathrm{O}-$ & - & - & - & - & - & +++ & ++++ & ++++ & - & - & $\mathrm{P}(-0.23)$ \\
\hline & & & & $\mathrm{C}-$ & - & - & - & - & - & - & - & - & - & - & \\
\hline \multirow[t]{2}{*}{768} & LD & 6 & Quail & $\mathrm{O}-$ & - & - & - & - & - & +++ & - & - & - & - & $\mathrm{N}(+0.02)$ \\
\hline & & & & $\mathrm{C}-$ & - & - & - & - & - & - & - & - & - & - & \\
\hline \multirow[t]{2}{*}{ A84 } & $\mathrm{LD}$ & 2 & Pheasant & $\mathrm{O}-$ & - & - & - & - & - & - & + & ++ & +++ & - & $\mathrm{P}(-0.43)$ \\
\hline & & & & $\mathrm{C}-$ & - & - & - & - & - & - & - & - & - & - & \\
\hline \multirow[t]{2}{*}{456} & LD & 3 & Pheasant & $\mathrm{O}-$ & - & - & - & - & - & - & - & - & - & - & $\mathrm{P}(-0.34)$ \\
\hline & & & & $\mathrm{C}-$ & - & - & - & - & - & - & - & - & - & - & \\
\hline \multirow[t]{2}{*}{1561} & HD & 9 & Mallard & $\mathrm{O}+++$ & ++ & ++ & - & - & - & - & - & $\mathrm{nd}^{\mathrm{e}}$ & nd & nd & $\mathrm{P}(-0.41)$ \\
\hline & & & & $\mathrm{C}-$ & - & ++++ & - & - & - & - & - & & & & \\
\hline \multirow[t]{2}{*}{1562} & HD & 9 & Mallard & $\mathrm{O}+$ & - & - & - & - & - & - & - & nd & nd & nd & $\mathrm{P}(-0.53)$ \\
\hline & & & & $\mathrm{C}-$ & - & - & - & - & - & - & - & & & & \\
\hline
\end{tabular}

${ }^{a}$ Animals with IDs shown in bold were experimentally infected

${ }^{\mathrm{b}} \mathrm{LD}=$ low-density stack; HD = high-density stack

c Animals from the high-density stack were bled on 10 DPI and animals from the low-density stack were bled on 15-16 DPI for serological analyses. $\mathrm{P}=$ positive; $\mathrm{N}=$ negative; $\mathrm{S}=$ suspect positive. The number in parentheses is the difference in $\mathrm{S} / \mathrm{N}$ ratios from pre- and postexperiment serum samples

${ }^{\mathrm{d}} \mathrm{O}=$ oral sample; $\mathrm{C}=$ cloacal sample; $+=$ positive for viral RNA $>10^{0}<10^{2} \log _{10} \mathrm{EID}_{50}$ equivalent $/ \mathrm{mL} ;++=>10^{2}<10^{3} \log _{10} \mathrm{EID}_{50}$ equivalent $/ \mathrm{mL} ;+++=>10^{3}<10^{4} \log _{10}$ EID $_{50}$ equivalent $/ \mathrm{mL} ;++++=>10^{4} \log _{10} \mathrm{EID}_{50}$ equivalent $/ \mathrm{mL} ;-=$ negative for viral RNA

${ }^{\mathrm{e}} \mathrm{nd}=$ not done

those located adjacent to their stack (Figure 2). Because of this, the experimental LBM with the high-density stack was terminated on 10 DPI at which time all animals were euthanized. Although experimentally inoculated mallards in the high-density stack had limited viral shedding, positive serological tests were noted in both of these mallards at 10 DPI, as both yielded sample-to-negative ratios clearly under previously described thresholds for this species [16].

\section{Low-density stack}

The LBM experiment with the low-density stack produced transmission to other bird species. Of interest, the single mallard deliberately infected in this stack shed only from the oral route from 1-3 DPI, but began to shed from the cloacal route at 4 DPI (Table 1). No shedding was detected from this mallard after 7 DPI. Its cage mate, which was not deliberately infected, occasionally shed from the oral route during early DPI and initiated cloacal shedding on 6 DPI. This mallard continued to shed viral RNA through 14 DPI. Thus, intra-cage transmission within this stack of cages resulted in the detection of viral RNA for up to seven additional days during the experimental period.

Two quail in cage 5 of the low-density stack shed virus from the oral route at 6 DPI and continued to shed virus until 9 DPI (Table 1; Figure 2). Of interest, both of these quail, as well as one quail from cage 6 , shed virus in quantities of up to $>10^{4.0} \mathrm{EID}_{50}$ equivalent $/ \mathrm{mL}$, which are greater quantities than any mallard shed during the duration of the low-density stack experiment (Table 1; Figure 2). 
A

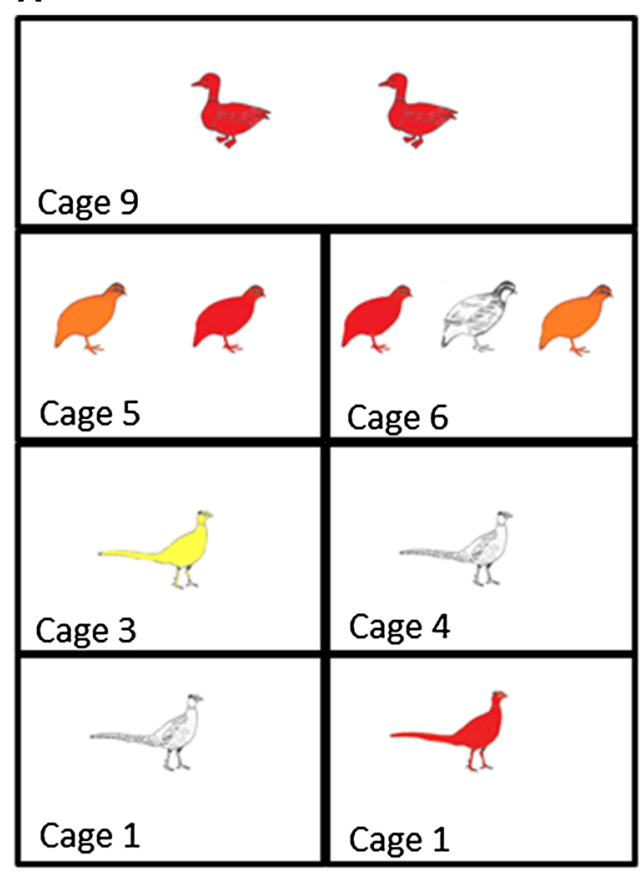

B

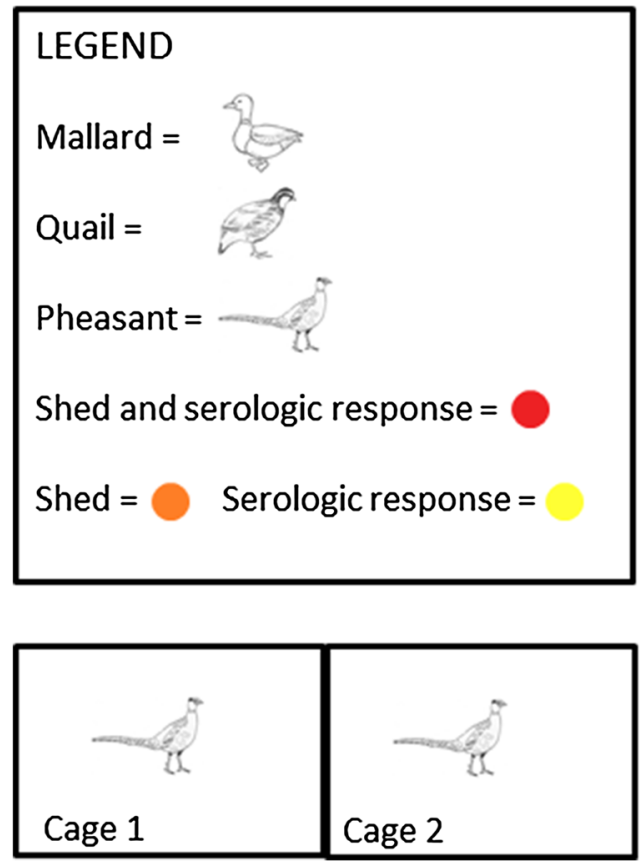

Fig. 2 Experimental outcome of a low-density (A) and high-density (B) simulated live bird market experimental transmission study. Shapes filled with red represent animals that shed viral RNA and seroconverted. Shapes filled with orange represent animals that shed

Two of three quail in cage 6 initiated viral shedding on 7 DPI. One quail shed through 11 DPI and the other only shed viral RNA for a single day. Thus, six days were required to initiate transmission of this virus from the index animal to interspecific bird species.


viral RNA but did not seroconvert during the study period. Shapes filled with yellow represent animals that seroconverted but did not shed detectable viral RNA. Animal drawings were produced by Elizabeth Draves and Jeremy W. Ellis

Evidence of transmission was limited to two of six pheasants located in the low-density stack (Figure 2). One pheasant from the fourth level of the stack showed evidence of shedding and seroconversion while the other from the third level only seroconverted. Oral shedding in 
the single pheasant initiated on 9 DPI and continued through 14 DPI (Table 1). Of interest, the pheasant that shed and seroconverted was located at the bottom of the low-density stack, which was the farthest distance possible within this stack from the index mallard. This suggests, along with the observation of no transmission occurring to pheasants located adjacent to index mallards (cages 7 and 8; Figure 1 and 2), that transmission to this pheasant was likely associated with fecal shedding or spilled water from mallards. Alternatively, considering that this pheasant did not produce viral shedding until after the shedding by quail located above it (cages 2 and 6; Figure 2; Table 1) was initiated, quail may have indirectly transmitted the virus to the pheasant, which may have been facilitated by the virus being passaged through a gallinaceous bird. If this were the case, transmission from quail to pheasants likely occurred through virusladen oral secretions from quail. No positive cloacal swabs were ever detected from quail or pheasants (Table 1), but positive environmental samples associated with both water and fecal samples (the feces sampled in a given cage were not necessarily representative of the species occupying that cage) were commonly found in cages housing both species (Table 2).

\section{Discussion}

The lack of observed transmission in the high-density stack was likely because the experimental infection of two mallards in this stack only appeared to produce a short duration infection in a single mallard, although a second mallard exhibited nominal viral RNA on a single DPI (Table 1). Therefore, this study clearly showed individual heterogeneity in shedding responses within hosts, similar to what has been observed previously in other species [8]. In addition, the infected mallard in the high-density stack only shed virus for a short duration and aside from a single day, only by the oral route. Thus, the inoculated mallards did not shed sufficient virus to infect their cage mates or the birds in adjacent or lower cages (Figure 2). Viral transmission in the high-density stack may have had a different outcome if shedding by other routes was more prevalent, as AIV shed via the fecal route by mallards can be rapidly transmitted among conspecifics when a shared water source, sufficient in size for fecal-oral transmission, is present [18]. Only small water sources were available in these pens, which precluded their use for bathing and swimming. Thus, a larger water source, although likely unrealistic in most LBM settings, may have facilitated more transmission. For example, relatively high quantities of virus have been reported in artificial waterbodies used by experimentally infected mallards [2].

The lack of transmission in the high-density stack was somewhat surprising, but is consistent with some other studies. For example, limited contact transmission was noted for experimentally infected (H7N9 A/Anhui/1/2013) Pekin ducks co-housed with naïve ducks [7]. We hypothesize that the lack of contact transmission among cohoused ducks is due to the lack of large shared water resources conducive of oral-fecal transmission. For example, others have shown successful transmission among mallards in contact with a water source previously contaminated by experimentally infected mallards [18] and water-associated transmission has also been postulated for mammals [12]. Overall, the index mallards in the highdensity stack appear to have shed virus for insufficient time and in insufficient quantities to elicit transmission within this stacked cage setting.

A previous simulated LBM study suggested that aerosol transmission was an important route in their study [23]. In the current study, in which a wild bird virus was used and chickens were absent from the experimental LBM setting, no clear evidence of aerosol transmission was observed. Considering that LP AIV is primarily a gastrointestinal disease of ducks, we did not expect to observe aerosol transmission in the index animals. Additionally, this is supported by several pieces of evidence. First, aside from a single co-caged mallard in cage 9 (Figure 2), evidence of transmission in the low-density stack was not observed until 6 DPI, one day after positive fecal and water environmental samples were detected in most other cages on 5 DPI (Tables 1 and 2). Second, environmental virus was not detected until 4 DPI in the low-density stack, the same day that cloacal shedding was first detected in this stack (Table 2). Third, if aerosols were a major source of transmission in the current experimental LBM, the finding of non-infected animals in cages above those animals that became infected during the study would appear unlikely (Figure 2). Notably, a previous study reported transmission to quail in stacked cages adjacent to (separated by one foot) cages housing index chickens infected with a poultry adapted virus, thereby suggesting that aerosol transmission was apparent for at least some of these birds [22]. Thus, aerosol transmission, as reported by others [22, 23], may be a more common mode of transmission of poultry-adapted H6N2 viruses in chickens as compared to the wild bird virus and avian species that we used.

Transmission to the single pheasant in level four (cage 2; Figures 1 and 2) of the low-density stack is likely attributed to one or more fecal samples or spilled water that passed through the other levels and landed in a location of 
Table 2 Influenza A viral RNA detections from environmental samples in a simulated live bird market. Only cages from the low-density stack are shown. Fecal samples are not necessarily representative of the animal or species in a given cage

\begin{tabular}{|c|c|c|c|c|c|c|c|c|c|c|c|c|c|}
\hline \multicolumn{3}{|c|}{ Experimental setup } & \multicolumn{11}{|c|}{ Days post infection (mallard) } \\
\hline Stack $^{\mathrm{a}}$ & Cage & Species & 1 & 2 & 3 & 4 & 5 & 6 & 7 & 9 & 11 & 14 & 16 \\
\hline \multirow[t]{2}{*}{ LD } & 1 & Pheasant & $\mathrm{F}^{\mathrm{a}}-$ & - & - & - & - & - & - & + & - & + & + \\
\hline & & & $\mathrm{W}-$ & - & - & - & + & +++ & $n d^{b}$ & nd & ++ & - & - \\
\hline \multirow[t]{2}{*}{ LD } & 2 & Pheasant & $\mathrm{F}-$ & - & - & - & + & +++ & - & ++ & - & + & + \\
\hline & & & $\mathrm{W}-$ & - & - & - & - & + & + & + & ++ & - & - \\
\hline \multirow[t]{2}{*}{ LD } & 3 & Pheasant & $\mathrm{F}-$ & - & - & - & + & + & - & - & - & ++ & - \\
\hline & & & $\mathrm{W}-$ & - & - & - & ++ & ++ & + & ++ & + & - & - \\
\hline \multirow[t]{2}{*}{$\mathrm{LD}$} & 4 & Pheasant & $\mathrm{F}-$ & - & - & - & - & ++ & + & - & ++ & - & ++ \\
\hline & & & $\mathrm{W}-$ & - & - & - & + & + & ++ & ++ & +++ & - & - \\
\hline \multirow[t]{2}{*}{ LD } & 5 & Quail & $\mathrm{F}-$ & - & - & - & - & ++ & - & +++ & - & - & + \\
\hline & & & $\mathrm{W}-$ & - & - & - & + & + & ++ & ++ & +++ & - & - \\
\hline \multirow[t]{2}{*}{ LD } & 6 & Quail & $\mathrm{F}-$ & - & - & - & ++ & + & + & ++ & ++ & + & - \\
\hline & & & $\mathrm{W}-$ & - & - & - & + & + & ++ & ++ & nd & - & - \\
\hline \multirow[t]{2}{*}{ LD } & 7 & Pheasant & $\mathrm{F}-$ & - & - & - & - & - & - & + & - & - & - \\
\hline & & & $\mathrm{W}-$ & - & - & - & - & - & - & - & - & - & - \\
\hline \multirow[t]{2}{*}{ LD } & 8 & Pheasant & $\mathrm{F}-$ & - & - & - & - & - & - & - & - & - & 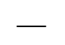 \\
\hline & & & $\mathrm{W}-$ & - & - & - & - & - & - & - & nd & nd & 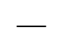 \\
\hline \multirow[t]{2}{*}{ LD } & 9 & Mallard & $\mathrm{F}-$ & - & - & + & ++++ & +++ & ++ & ++ & +++ & - & + \\
\hline & & & W nd & - & - & ++ & +++ & +++ & nd & +++ & nd & nd & nd \\
\hline
\end{tabular}

${ }^{\mathrm{a}} \mathrm{F}=$ fecal sample; $\mathrm{W}=$ water sample; $+=$ positive for viral RNA $>10^{0}<10^{2} \log _{10} \mathrm{EID}_{50}$ equivalent $/ \mathrm{mL}$; $++=>10^{2}<10^{3} \log _{10}$ EID $_{50}$ equivalent $/ \mathrm{mL} ;+++=>10^{3}<10^{4} \log _{10}$ EID $_{50}$ equivalent $/ \mathrm{mL} ;++++=$ $>10^{4} \log _{10} \mathrm{EID}_{50}$ equivalent $/ \mathrm{mL} ;-=$ negative for viral RNA

b $\mathrm{nd}=$ not done (e.g., no sample available) the pheasant's cage, such as its food or water dish, that facilitated transmission. Thus, chance, at least to some degree, is likely involved in transmission within LBMs, especially in instances when viruses are not prone to be transmitted by the aerosol route. An additional pheasant located in cage 3 showed no evidence of shedding viral RNA but did show evidence of seroconversion (Table 1; Figure 2). This suggests that this bird was exposed to small quantities of virus, likely sufficient to initiate a serological response, but insufficient to produce viral replication. Alternatively, this bird may have shed virus on a day that we did not sample or may have shed an amount of virus that was under the threshold of detection of our RT-PCR assay. A similar observation, in which a high proportion of Pekin ducks in an experimental LBM yielded positive hemagglutinin inhibition tests, but only one duck was positive by RT-PCR, has been reported prevsiously [22].

Except for the index animals, quail exhibited the greatest proportion of animals infected, with $80 \%$ showing evidence of shedding on at least one DPI in the low-density stack (Table 1). Nonetheless, two quail failed to seroconvert by the termination of this experiment. A similar observation has been described previously in chickens [23]. One potential explanation for the one quail that only shed on 7 DPI is that the apparent shedding observed in this animal was simply associated with the ingestion of virusladen water [20], as viral RNA was detected on several DPI in the water bowls of both quail cages (Table 2). However, this explanation appears unlikely for the second quail that failed to seroconvert, as this bird shed during 6-9 DPI, and shed in greater quantities than its cage-mate, which was the only other quail shedding on 6 DPI (Table 1). The observation that quail represent a high proportion of all infected birds in simulated LBMs has been reported previously for emergent H7N9 IAV [3]. Given the high proportion of quail that shed virus during the current study and in other studies, quail may be important species for transmission in experimental LBMs; consequently, quail warrant additional scrutiny in their roles in the transmission of AIVs in LBM settings [3, 22].

The current study demonstrated that a wild bird virus can be transmitted to multiple avian species commonly found in LBM settings. Consistent with a pervious study [23], inter-cage transmission took several days to occur among stacked cages, likely associated with the index animal(s) shedding virus in insufficient quantities to initiate transmission during early DPI. Thus, this suggests that LBMs with complete and frequent turnovers of animals may be at reduced risk for transmission. Additional studies are needed to assess management practices for the 
positioning of animals in these types of settings to limit viral transmission.

Acknowledgements We thank the NWRC animal care staff for excellent assistance and L. Peterson and N. Mooers for assistance with processing birds. In addition, we thank T. Cochran, K. Bentler, and $\mathrm{H}$. Sullivan for laboratory support. The opinions and conclusions of this article are those of the authors and do necessarily represent those of the U.S. Department of Agriculture. The mention of commercial products herein is for identification purposes only and does not constitute endorsement or censure.

\section{Compliance with ethical standards}

Funding This research was supported by the U.S. Department of Agriculture.

Conflict of interest The authors declare that they have no conflict of interest.

Ethical approval All applicable international, national, and/or institutional guidelines for the care and use of animals were followed.

\section{References}

1. Abdelwhab EM, Selim AA, Arafa A, Galal S, Kilany WH, Hassan MK, Aly MM, Hafez MH (2010) Circulation of avian influenza $\mathrm{H} 5 \mathrm{~N} 1$ in live bird markets in Egypt. Avian Dis 54:911-914

2. Achenbach JE, Bowen RA (2011) Transmission of avian influenza A viruses among species in an artificial barnyard. PLoS One 6:e17643

3. Bosco-Lauth AM, Bowen RA, Root JJ (2016) Limited transmission of emergent H7N9 influenza A virus in a simulated live animal market: do chickens pose the principal transmission threat? Virology 495:161-166

4. Bulaga LL, Garber L, Senne DA, Myers TJ, Good R, Wainwright S, Trock S, Suarez DL (2003) Epidemiologic and surveillance studies on avian influenza in live-bird markets in New York and New Jersey, 2001. Avian Dis 47:996-1001

5. Cardona C, Yee K, Carpenter T (2009) Are live bird markets reservoirs of avian influenza? Poult Sci 88:856-859

6. Landes M, Persaud S, Dyck J (2004) Poultry marketing and prices. India's poultry sector: development and prospects. U.S. Department of Agriculture, Agriculture and Trade Report WRS04-03:18-24

7. Pantin-Jackwood MJ, Miller PJ, Spackman E, Swayne DE, Susta L, Costa-Hurtado M, Suarez DL (2014) Role of poultry in the spread of novel H7N9 influenza virus in China. J Virol 88:5381-5390

8. Pepin KM, VanDalen KK, Mooers NL, Ellis JW, Sullivan HJ, Root JJ, Webb CT, Franklin AB, Shriner SA (2012) Quantification of heterosubtypic immunity between avian influenza subtypes H3N8 and H4N6 in multiple avian host species. J Gen Virol 93:2575-2583

9. Pepin KM, Wang J, Webb CT, Smith GJD, Poss M, Hudson PJ, Hong W, Zhu H, Riley S, Guan Y (2013) Multiannual patterns of influenza A transmission in Chinese live bird market systems. Influenza Other Respir Viruses 7:97-107

10. Piaggio AJ, Shriner SA, VanDalen KK, Franklin AB, Anderson TD, Kolokotronis SO (2012) Molecular surveillance of low pathogenic avian influenza viruses in wild birds across the United States: inferences from the hemagglutinin gene. PLoS One 7:e50834

11. ProMED-mail (2016) Avian Influenza (64): USA, LPAI H5. ProMed-Mail 20160714.4346097

12. Root JJ, Bentler KT, Shriner SA, Mooers NL, VanDalen KK, Sullivan HJ, Franklin AB (2014) Ecological routes of avian influenza virus transmission to a common mesopredator: an experimental evaluation of alternatives. PLoS One 9:e102964

13. Root JJ, Shriner SA, Ellis JW, VanDalen KK, Sullivan HJ, Franklin AB (2015) When fur and feather occur together: interclass transmission of avian influenza A virus from mammals to birds through common resources. Sci Rep 5:12354

14. Senne DA, Pedersen JC, Panigrahy B (2005) Live-bird markets in the Northeastern United States: a source of avian influenza in commercial poultry. Wageningen UR Frontis Series 8:19-24

15. Shriner SA, VanDalen KK, Mooers NL, Ellis JW, Sullivan HJ, Root JJ, Franklin AB (2012) Low-pathogenic avian influenza viruses in wild house mice. PLoS One 7:e39206

16. Shriner SA, VanDalen KK, Root JJ, Sullivan HJ (2016) Evaluation and optimization of a commercial blocking ELISA for detecting antibodies to influenza A virus for research and surveillance of mallards. J Virol Methods 228:130-134

17. Spackman E, Senne DA, Bulaga LL, Myers TJ, Perdue ML, Garber LP, Lohman K, Daum LT, Suarez DL (2003) Development of real-time RT-PCR for the detection of avian influenza virus. Avian Dis 47:1079-1082

18. VanDalen KK, Franklin AB, Mooers NL, Sullivan HJ, Shriner SA (2010) Shedding light on avian influenza H4N6 infection in mallards: modes of transmission and implications for surveillance. PLoS One 5:e12851

19. Webster RG (2004) Wet markets - a continuing source of severe acute respiratory syndrome and influenza? Lancet 363:234-236

20. Wille M, Van Run P, Waldenström J, Kuiken T (2014) Infected or not: are PCR-positive oropharyngeal swabs indicative of low pathogenic influenza A virus infection in the respiratory tract of Mallard Anas platyrhynchos? Vet Res 45:53

21. Wisedchanwet $\mathrm{T}$, Wongphatcharachai $\mathrm{M}$, Boonyapisitsopa $\mathrm{S}$, Bunpapong N, Kitikoon P, Amonsin A (2011) Genetic characterization of avian influenza subtype H4N6 and H4N9 from live bird market, Thailand. Virol J 8:131

22. Yee KS, Cardona CJ, Carpenter TE (2009) Transmission of lowpathogenicity avian influenza virus of subtype H6N2 from chickens to Pekin ducks and Japanese quail (Coturnix coturnix japonica). Avian Pathol 38:59-64

23. Yee KS, Carpenter TE, Farver TB, Cardona CJ (2009) An evaluation of transmission routes for low pathogenicity avian influenza virus among chickens sold in live bird markets. Virology 394:19-27

24. Yee KS, Novick CA, Halvorson DA, Dao N, Carpenter TE, Cardona CJ (2011) Prevalence of low pathogenicity avian influenza virus during 2005 in two U.S. live bird market systems. Avian Dis 55:236-242 